\title{
Evaluasi Pembelajaran IPA Model Discovery Learning Menggunakan Model Countenance Stake
}

\author{
Putri Rahadian Dyah Kusumawati \\ Fakultas Tarbiyah dan Ilmu Keguruan, IAIN Pekalongan \\ Jl. Kusuma Bangsa No.9, Panjang Baru, Pekalongan Utara, Kota Pekalongan, Jawa Tengah 51141 \\ Email: putri.rahadian.dyah.kusumawati@iainpekalongan.ac.id
}

\begin{abstract}
Abstrak
Penelitian ini bertujuan untuk mengetahui: (1) kualitas persiapan, (2) kualitas implementasi, dan (3) hasil belajar siswa dalam penerapan pembelajaran sains dalam Kurikulum 2013. Penelitian ini merupakan model evaluasi penelitian berdasarkan Model Countenance Stake. Populasi dalam penelitian ini adalah guru dan siswa di kelas 7 SMP. Penelitian ini dilakukan di SMP yang menerapkan Kurikulum 2013 di wilayah Bantul. Sampel guru ditentukan dengan teknik purposive sampling. Sampel siswa ditentukan dengan teknik proporsional random sampling. Data dikumpulkan dengan menggunakan lembar review persiapan dokumen, observasi kelas, kuesioner siswa dan guru, dan dokumen hasil belajar siswa. Data dianalisis dengan teknik deskriptif kuantitatif. Hasil penelitian menunjukkan kepedulian yang kuat antara kualitas persiapan guru, implementasi dan hasil belajar siswa. Hasil penelitian ini menunjukkan bahwa: (1) kualitas persiapan pembelajaran IPA dalam Kurikulum 2013 dikategorikan baik (t-score = 50,51), (2) kualitas penerapan pembelajaran IPA di Kurikulum 2013 adalah dikategorikan baik $(t$-score $=51,32)$, (3) hasil hasil belajar siswa dikategorikan baik $(t$-score $=50,59)$.
\end{abstract}

Kata Kunci: model discovery learning, pembelajaran IPA, evaluasi

\begin{abstract}
This research aims were: (1) the quality of preparation, (2) the quality of implementation, and (3) the learning outcomes of students in application of learning science in Curriculum 2013. This research was model evaluation research based on Countenance Stake model. The population in this study was teachers and students in seventh grade of Junior High School. This research was conducted in Junior High School that was applying Curriculum 2013 in Bantul region. The teacher sample was determined by purposive sampling technique. The student sample was determined by proportional random sampling technique. The data were collected using document preparation review sheets, classroom observations, student and teacher questionnaires, and document of student learning outcomes. The data were analyzed by descriptive quantitative technique. The results indicated a strong concerned between the quality of teacher preparation, implementation and student learning outcomes. The result of this research show that: (1) the quality of preparation of learning science in Curriculum 2013 was categorized good (t-score $=50,51)$, (2) the quality of implementation of learning science in Curriculum 2013 was categorized good (t-score $=51,32)$, (3) the result of student learning outcomes was categorized good ( $t$-score $=50,59)$.
\end{abstract}

Keywords: discovery learning, science learning, evaluation 


\section{PENDAHULUAN}

Pembelajaran di era revolusi industri 4.0 diarahkan untuk mendorong peserta didik mencari pengetahuan dari berbagai sumber observasi untuk mampu merumuskan masalah, berpikir analisis (pengambilan keputusan), dan menekankan pentingnya kerjasama dalam menyelesaikan masalah. Hal ini menjadi penting untuk mempersiapkan generasi yang mampu menyelesaikan berbagai isu global. Kurikulum yang digunakan saat ini mengharapkan guru dapat melaksanakan pembelajaran dengan pendekatan saintifik. Metode ilmiah menjadi kerangka dasar dalam proses pembelajaran.

Paradigma dan konsep kurikulum tersebut membutuhkan persiapan yang baik terutama oleh stakeholder yang berperan dalam pelaksanaan kurikulum. Guru merupakan bagian penting dalam pelaksanaan pembelajaran. Guru harus mempersiapkan pembelajaran dengan sebaik mungkin sehingga dapat melaksanakan pembelajaran dengan baik pula. Guru juga berperan sebagai pemimpin dan kreator dalam pembelajaran. Oleh karena itu, guru perlu memahami dengan benar karakteristik pembelajaran yang dikehendaki.

IPA merupakan ilmu pengetahuan yang mempelajari tentang fenomena dan gejala alam melalui proses ilmiah. IPA merupakan bagian pengetahuan tentang alam yang dihasilkan melalui pengamatan, mengeksplorasi, menemukan dan berpikir rasional (P. G. Hewitt et al., 2013). Di samping itu IPA dapat dikaji dari sebagai cara berpikir (a way of thinking) dalam memahami alam, cara penyelidikan $(a$ way of investigation) tentang fenomena dan bangunan ilmu (body of knowledge) hasil dari proses penyelidikan (Collette \& Chiapetta, 1994, p.30). Pengertian tersebut menjelaskan bahwa IPA tidak hanya tentang penguasaan konsep alam tetapi juga proses penemuan serta nilai yang terkandung di dalamnya. Oleh karena itu, pembelajaran IPA yang dilaksanakan di sekolah harus sesuai dengan hakikat IPA.

Pembelajaran IPA di SMP sesuai dengan Kurikulum 2013 dikembangkan bukan hanya sebagai suatu disiplin ilmu tetapi sebagai mata pelajaran integrative science. Pembelajaran IPA bersifat interdisipliner yang mencakup pengetahuan, keterampilan dan sikap. Pembelajaran IPA berorientasi aplikatif, mampu mengembangkan kemampuan berpikir, menumbuhkan rasa ingin tahu, dan membangun sikap tanggung jawab terhadap lingkungan sekitar. Selain itu, pembelajaran IPA dalam Kurikulum 2013 juga mengupayakan untuk dilakukan melalui proses metode ilmiah dengan pendekatan saintifik. Langkah dalam proses pembelajaran IPA dikembangkan dengan menggunakan pendekatan ilmiah dan diperkuat dengan berbagai model pembelajaran.

Discovery learning tidak menyediakan pemahaman konseptual secara langsung tetapi peserta didik harus menemukan sendiri dengan materi yang disediakan (Alfieri et al., 2011). Discovery learning yang diterapkan dalam pembelajaran IPA mengutamakan proses metode ilmiah yaitu menalar, mencoba serta pemecahan masalah (Arend, 2014, p.411). Secara operasional pelaksanaan model discovery learning terdiri dari enam tahapan yaitu stimulation (stimulasi/pemberian rangsangan), problem statement (pernyataan/identifikasi masalah), data collection (pengumpulan data), data processing (pengolahan data), verification (pembuktian), dan generalization (menarik kesimpulan/generalisasi) (Syah, 2008, p.244). Langkah-langkah dalam pendekatan discovery learning memperkuat kompetensi siswa dalam melakukan metoda ilmiah. Oleh karena itu, kegiatan pembelajaran dalam Kurikulum 2013 sangat disarankan menerapkan belajar berbasis penyingkapan (discovery learning) untuk memperkuat pendekatan saintifik, terpadu dan tematik yang digunakan dalam pembelajaran (Mendikbud, 2013, p.9).

Evaluasi merupakan proses klarifikasi untuk melihat kesesuaian suatu pelaksanaan program dengan perencanaan tersebut berdasarkan standar kriteria tertentu. Hasil proses evaluasi tersebut dapat digunakan untuk perbaikan dan menentukan keberlanjutan program yang dievaluasi. Hal ini sesuai dengan pendapat bahwa evaluasi didefinisikan sebagai 
identifikasi, klarifikasi, dan aplikasi dari kriteria untuk menjelaskan kepantasan atau kesesuaian objek yang dievaluasi dengan kriteria tersebut (Fitzpatrick, Sanders \& Worthen, 2011, p.7). Ruang lingkup evaluasi pembelajaran mencakup perencanaan pembelajaran, proses pelaksanaan pembelajaran dan hasil pembelajaran (Arifin, 2014, p.24-25). Penjelasan tersebut menunjukkan bahwa evaluasi pembelajaran harus mencakup tiga tahapan yaitu persiapan/ perencanaan, pelaksanaan, dan penilaian hasil belajar serta dibandingkan dengan kriteria tertentu.

Berdasarkan uraian tersebut maka model evaluasi yang tepat digunakan dalam penelitian ini adalah model evaluasi countenance stake. Model countenance terdiri atas matrik deskripsi (description matrix) dan matrik pertimbangan (judgment matrix) (Stake, 1967). Matrik deskripsi terdiri atas tujuan (intens) dan observasi (observations), sedangkan matrik pertimbangan terdiri atas standar (standard) dan pertimbangan (judgment). Setiap matrik ditinjau dalam tiga tahap yaitu antecendent (sebelum/masukan), transactions (proses), dan outcomes (hasil). Antecendent (sebelum/ masukan) merupakan kondisi sebelum proses yang dapat mempengaruhi hasil, transactions merupakan proses interaksi yang terjadi antar komponen, sedangkan outcomes merupakan hasil yang akan diperoleh setelah proses (Stake, 1967). Transactions menghubungkan antara antecendent dengan outcomes. Ketiga tahap dalam evaluasi tersebut dilakukan pada matrik deskripsi maupun matrik pertimbangan.

Pada tahap perencanaan (intent), evaluator menganalisis keterkaitan logis (contingency logis) dari tahap antecendent, transactions, dan outcomes. Evaluator melakukan pertimbangan tahap pertama. Data hasil observasi dianalisis keterkaitan empiriknya (contingency empirik). Keterkaitan antara tahap antecendent, transactions, dan outcomes diamati berdasarkan data di lapangan. Evaluator melakukan pertimbangan tahap kedua. Analisis yang harus dilakukan evaluator berikutnya yaitu menganalisis kesesuaian (congruence) antara rencana dengan hasil observasi di lapangan. Hasil evaluasi dikatakan congruence apabila memiliki kesesuaian dengan tujuan awal yang diharapkan. Dengan demikian ada tiga tahapan pertimbangan yaitu hasil keterkaitan logis, keterkaitan empirik dan kesesuaian antara rencana dan kenyataan.

Hasil penelitian yang dilakukan oleh Astin Lukum (2015) yang berjudul "Evaluasi Program Pembelajaran IPA SMP Menggunakan Model Countenance Stake", menunjukkan perencanaan termasuk kategori cukup, karena RPP yang dibuat belum sesuai dengan standar proses pembelajaran; b) pelaksanaan kategori cukup, antara pelaksanaan pembelajaran dengan standar proses pelaksanaan pembelajaran belum sesuai; c) hasil belajar peserta didik belum memenuhi Kriteria Ketuntasan Minimal (KKM) dengan aktualitas ketercapaian kategori cukup; dan d) terdapat contingency antara perencanaan, pelaksanaan dengan hasil belajar IPA, yang perencanaan pembelajaran dengan kategori cukup menyebabkan guru melaksanakan pembelajaran belum sesuai standar proses sehingga hasil belajar peserta didik belum memenuhi KKM. Penelitian ini telah cukup lama dilaksanakan. Selain itu, penelitian ini juga masih hanya dilakukan di salah satu kabupaten saja. Oleh karena itu, perlu dilakukan penelitian yang memiliki jangkauan yang lebih luas.

Penelitian evaluasi ini diharapkan dapat memberikan informasi secara empiris mengenai keterlaksanaan dan kualitas pembelajaran IPA di SMP penerapan Kurikulum 2013 yang meliputi aspek persiapan, penerapan, dan perolehan hasil belajar peserta didik setelah penerapan model discovery learning dalam pembelajaran IPA Kurikulum 2013 di SMP Kabupaten Bantul. Pertimbangan pada penelitian ini didasarkan pada standar dalam Kurikulum 2013 yaitu guru mempersiapkan pembelajaran sesuai dengan Permendikbud No. 65 tahun 2013 tentang standar proses dan No. 103 tahun 2014 tentang pembelajaran pada pendidikan dasar dan menengah, sesuai dengan tahapan model discovery learning Kurikulum 2013, Permendikbud nomor 66 tahun 2013 
dan 104 tahun 2014 tentang penilaian hasil belajar. Ketercapaian hasil belajar peserta didik didasarkan pada Kriteria Ketuntasan Minimal (KKM).

\section{Metode Penelitian}

Penelitian ini merupakan penelitian evaluasi program menggunakan pendekatan deskriptif kuantitatif. Model evaluasi yang digunakan yaitu model evaluasi Countenance Stake. Penelitian ini dilaksanakan di SMP Negeri yang berlokasi di Kabupaten Bantul, Provinsi D.I. Yogyakarta.

Populasi dalam penelitian ini yaitu seluruh peserta didik dan guru IPA di SMP Kabupaten Bantul. Teknik pengambilan sampel untuk guru dilakukan dengan purposive sampling sesuai tujuan penelitian ini maka diambil sampel guru mata pelajaran IPA kelas VII. Dengan asumsi bahwa kemampuan guru IPA relatif sama pada masing-masing sekolah diwakili oleh satu orang guru. Teknik pengambilan sampel peserta didik menggunakan propotional random sampling dengan didasarkan pada pertimbangan proporsi dari sebaran wilayah sampel. Penarikan jumlah sampel peserta didik menggunakan rumus yang dikembangkan oleh Isaac and Michael (Sugiyono, 2014, p.87).

$$
s=\frac{\lambda^{2} \cdot N \cdot P \cdot Q}{d^{2}(N-1)+\lambda^{2} \cdot P \cdot Q}
$$

Keterangan:

$s=$ jumlah sampel

$N=$ ukuran populasi

$P=$ proporsi populasi, dengan $P=0,5=Q$

$d=$ derajat ketepatan, dengan $d=0,05$

$\lambda^{2}=$ nilai chi square $d k=1$, taraf kesalahan $5 \%$

Jumlah sampel peserta didik yang diperoleh berdasarkan perhitungan tersebut sebesar 282 peserta didik. Jumlah ini kemudian dibagi sesuai proporsi jumlah peserta didik pada 6 SMP di Kabupaten Bantul. Jumlah sampel tersebut terbagi menjadi dua atau tiga kelas penelitian pada masing-masing sekolah bergantung proporsi setiap sekolah. Pemilihan kelas penelitian dalam sekolah menyesuaikan guru kelas pengampu kelas VII sebagai subjek penelitian.

\section{Prosedur}

Tahapan yang dilakukan dalam penelitian ini mengadaptasi tahapan penelitian evaluasi model countenance stake yang terdiri terdiri atas matrik deskripsi (description matrix) dan matrik pertimbangan (judgment matrix). Matrik deskripsi terdiri atas tujuan (intens) dan observasi (observations), sedangkan matrik pertimbangan terdiri atas standar (standard) dan pertimbangan (judgment). Setiap matrik ditinjau dalam tiga tahap yaitu antecendent (persiapan), transactions (proses), dan outcomes (hasil). Proses intent dilakukan dengan menganalisis keterkaitan logis (contingency logis) dari tahap antecendent, transactions, dan outcomes. Langkah berikutnya yaitu melakukan observasi terhadap tiga tahap tersebut. Analisis congruence (kesesuaian) antara rencana pada kategori intent dengan implementasi dilakukan saat observasi. Hasil analisis tersebut kemudian dibandingkan dengan standar evaluasi yang telah ditentukan sebelumnya. Hasil analisis tersebut menghasilkan suatu pertimbangan dan rekomendasi. Bagan proses penelitian evaluasi ini terdapat dalam Gambar 1.

\section{Data, Instrumen, dan Teknik Pengumpulan Data}

Pengumpulan data dan informasi menggunakan teknik dokumentasi menggunakan instrumen lembar telaah dokumen, observasi menggunakan lembar observasi dan kuesioner menggunakan lembar angket. Teknik dokumentasi digunakan untuk mengumpulkan data yang berkaitan dengan kesiapan guru dalam perencanaan pembelajaran model discovery learning berupa RPP. Dokumen daftar nilai harian digunakan sebagai sumber data ketercapaian hasil belajar peserta didik. Teknik observasi digunakan untuk mendapatkan data melalui pengamatan tentang proses pelaksanaan pembelajaran. Teknik kuesioner pada penelitian ini digunakan untuk mengumpulkan informasi 


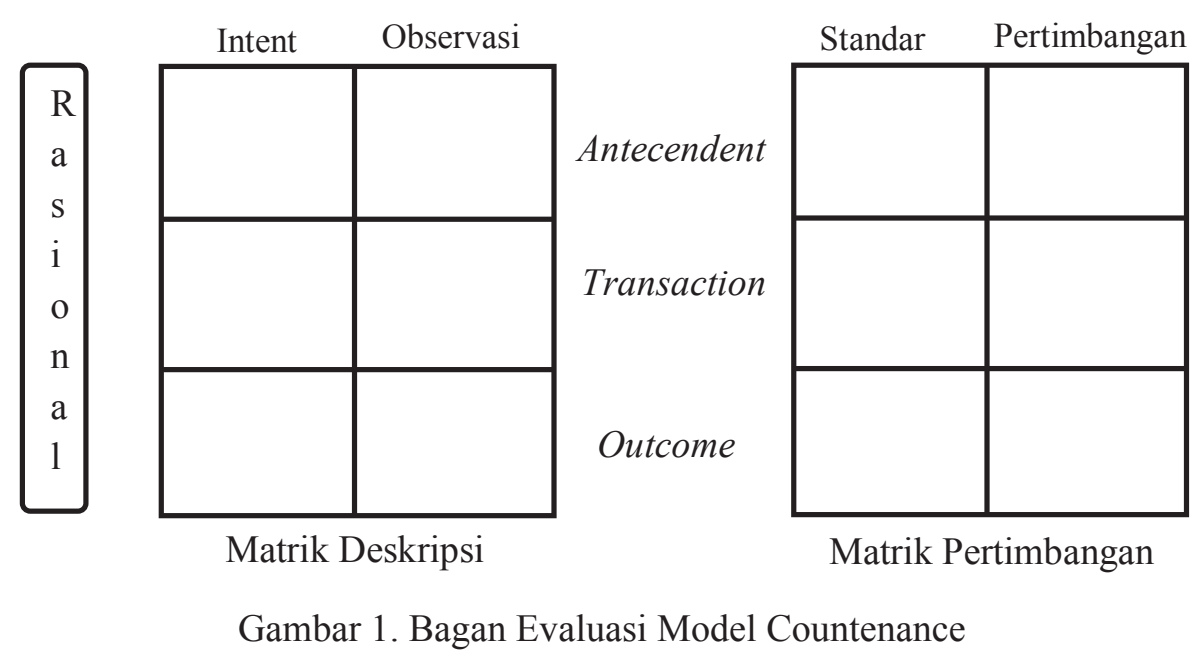

(Stake, 1967)

dari guru IPA dan peserta didik SMP kelas VII. Lembar angket pendidik digunakan untuk mengumpulkan data tentang perencanaan, pelaksanaan dan penilaian pembelajaran IPA yang dilaksanakan guru tersebut. Lembar angket peserta didik digunakan untuk mengumpulkan data tentang pelaksanaan pembelajaran dari perspektif peserta didik.

\section{TEKNIK ANALISIS DATA}

Penentuan persentase ketercapaian penerapan berdasarkan perhitungan persentase kategori yang diperoleh dengan persamaan sebagai berikut.

Persentase penerapan $=\frac{x}{x_{\max }} \times 100 \%$

Keterangan :

$x \quad$ : Frekuensi kategori yang diperoleh

$x_{\max }$ : Frekuensi maksimal

Teknik analisis data yang digunakan adalah analisis deskriptif kuantitatif. Data yang diperoleh dari masing-masing instrumen diubah dalam bentuk skor sesuai dengan kriteria skor yang telah ditetapkan sebelumnya. Skor mentah yang diperoleh kemudian diubah menjadi skor baku (standard scorel z-score). Skor yang diperoleh melalui perhitungan $z$-score dapat menunjukkan nilai negatif untuk skor dibawah rerata. Oleh karena itu, z-score perlu dikonversi dalam $t$-score. Perolehan $t$-score kemudian dibandingkan dengan kriteria evaluasi pada Tabel 1.
Tabel 1. Kriteria Evaluasi

\begin{tabular}{ll}
\hline \multicolumn{1}{c}{ Interval Skor } & \multicolumn{1}{c}{ Kategori } \\
$X>\overline{X_{t}}+1,8 S B_{i}$ & Sangat Baik \\
$\overline{X_{t}}+0,6 S B_{i}<X \leq \overline{X_{t}}+1,8 S B_{i}$ & Baik \\
$\overline{X_{t}}-0,6 S B_{i}<X \leq \overline{X_{t}}+0,6 S B_{i}$ & Cukup \\
$\overline{X_{t}}-1,8 S B_{i}<X \leq \overline{X_{t}}-0,6 S B_{i}$ & Kurang \\
$X \leq \overline{X_{t}}-1,8 S B_{i}$ & Sangat Kurang \\
\hline
\end{tabular}

Keterangan:

$\overline{X_{1}}:$ rerata ideal $=\frac{1}{2}($ skor maksimum + skor minimum)

$S B_{i}:$ simpangan baku ideal $=\frac{1}{6}($ skor maksimum + skor minimum)

$X \quad$ : skor yang diperoleh $X_{\max }$

(Widoyoko, 2015, p.238)

Sesuai dengan model evaluasi Countenance Stake, analisis dilakukan dengan melihat keterkaitan logis dan empirik antara antecendent, transactions dan outcomes, serta kesesuaian antara rencana dan kenyataan. Hasil analisis tersebut kemudian disimpulkan untuk dapat menyusun rekomendasi-rekomendasi tertentu.

\section{HASIL PENELITIAN DAN PEMBAHASAN}

Hasil penelitian ini mencakup tiga aspek yaitu persiapan (antecendent), pelaksanaan (transaction), dan hasil belajar (outcomes). Pembahasan akan mencakup keterkaitan (contingency) logis dan empirik antara antecendent, transaction dan outcomes, serta 
kesesuaian (congruence) antara rencana dan kenyataan.

\section{Keterkaitan (Contingency)}

Implementasi pembelajaran yang maksimal dapat diperoleh dengan menerapkan langkah pembelajaran yang sesuai dengan RPP yang baik. Keberhasilan guru dalam menerapkan RPP yang telah dirancang mengakibatkan guru dapat melaksanakan pembelajaran dengan efektif dan efisien. Efektif dalam mencapai indikator pembelajaran yang diinginkan dan efisien dalam mengalokasikan waktu yang tersedia. Pelaksanaan pembelajaran yang baik dapat menunjukkan kemampuan guru dalam menerapkan standar proses pembelajaran. Peserta didik menunjukkan keaktifan dalam pembelajaran terutama pada proses pengamatan maupun menyampaikan hasil pengamatan. Peserta didik sebagian besar terlihat bersemangat menyelesaikan berbagai kegiatan dalam pembelajaran. Hal ini menunjukkan keberhasilan penerapan Kurikulum dalam jangka waktu yang relative singkat dilihat dari segi proses yaitu apabila sebagian besar peserta didik aktif, bersemangat, dan percaya diri dalam proses pembelajaran (Mulyasa, 2015, p.131).

Pelaksanaan pembelajaran yang baik akan berdampak pada penilaian hasil belajar peserta didik. Secara keseluruhan pelaksanaan penilaian hasil belajar IPA peserta didik termasuk dalam kategori baik menunjukkan guru telah mampu melaksanakan sebagian besar standar proses penilaian pembelajaran Kurikulum 2013. Secara khusus penilaian berkategori baik pada penilaian aspek pengetahuan, analisis dan pelaporan. Hasil belajar peserta didik juga menunjukkan sebagian besar peserta didik telah mencapai KKM. Hal ini menunjukkan bahwa pembelajaran yang dilakukan dapat menjadi sarana menyampaikan materi dengan baik, sehingga peserta didik dapat memahami konsep dengan baik. Hal ini sejalan dengan pendapat bahwa pembelajaran penemuan sebagai pengalaman belajar yang berpusat pada siswa membantu siswa memahami pengetahuan baru karena mereka membangun kepercayaan mereka sendiri tentang dunia di sekitar mereka (Champine et al., 2009).

Ketidaksesuaian perencanaan pembelajaran dapat berdampak pada pelaksanaan dan penilaian hasil belajar peserta didik. Kendala yang dialami guru dalam merancang RPP dengan model discovery learning masih belum memunculkan komponen untuk memotivasi peserta didik merumuskan pertanyaan, prediksi maupun hipotesis (problem statement). Perencanaan yang kurang baik ini mengakibatkan pada pelaksanaan pembelajaran guru jarang terlihat dalam proses membimbing peserta didik merumuskan prediksi maupun hipotesis. Ketiadaan proses ini menyebabkan peserta didik masih menemui kesulitan merumuskan pertanyaan, prediksi, dan hipotesis (problem statement). Seharusnya dalam pembelajaran penemuan (discovery learning) menyajikan pertanyaan dan kegiatan yang menantang siswa untuk memanfaatkan pengetahuan mereka sebelumnya sehingga dapat membangun dan meningkatkan pemahaman mereka saat ini (Champine et al., 2009). Ketidaksesuaian ini juga dimungkinkan karena perencanaan guru dalam muatan konsep IPA terpadu masih terbatas sehingga muatan konsep yang tersampaikan kepada peserta didik kurang berkembang. Pemilihan sumber dan media pembelajaran sebenarnya dapat membantu guru dalam memotivasi peserta didik untuk merangsang rasa keingintahuannya. Rasa ingin tahu yang tinggi dapat mendorong peserta didik untuk dapat merumuskan prediksi maupun hipotesis dari masalah yang mereka amati. Keterkaitan antar aspek ini sejalan dengan hasil penelitian bahwa terdapat contingency antara perencanaan, pelaksanaan dan hasil belajar peserta didik dalam pembelajaran IPA di SMP (Lukum, 2015).

\section{Kesesuaian (Congruence) Antecendent (Persiapan Pembelajaran)}

Persiapan pembelajaran dirancang oleh guru melalui pembuatan perangkat pembelajaran berupa RPP(Rencana Pelaksanaan Pembelajaran). Hasil persiapan pembelajaran 
model discovery learning dalam pembelajaran IPA di SMP disajikan dalam Tabel 2. Kesesuaian antara intent dengan observasi menunjukkan bahwa guru telah memiliki kompetensi yang cukup untuk dapat menerapkan pembelajaran yang sesuai dengan kurikulum.

Beberapa komponen dalam persiapan pembelajaran yang dibuat guru belum mencapai standar yang diharapkan. Pada perencanaan kegiatan pendahuluan dibuat oleh guru belum memuat penyampaian teknik penilaian kepada peserta didik di awal pembelajaran. Pada kegiatan inti, perencanaan model discovery learning masih belum memunculkan komponen untuk memotivasi peserta didik merumuskan pertanyaan, prediksi maupun hipotesis (problem statement). Temuan lainnya pada kegiatan penutup, persentase frekuensi kemunculan komponen merencanakan kegiatan tindak lanjut. Perencanaan materi ajar yang dibuat guru belum secara keseluruhan memuat konsep IPA terpadu. Konsep IPA terpadu seharusnya telah dirancang oleh guru sebelum pembuatan RPP sehingga pengetahuan yang diperoleh peserta didik bersifat menyeluruh. Perencanaan pembelajaran yang dibuat guru juga masih rendah frekuensi kemunculannya yaitu komponen pemilihan sumber dan media pembelajaran. Guru perlu meningkatkan kreativitas sehingga media pembelajaran yang dilakukan lebih menarik, bervariasi dan memberikan ruang yang cukup untuk kreativitas. Hasil yang sama ditemukan bahwa kesulitan yang dialami guru IPA SMP dalam menyusun RPP yaitu memilih materi ajar yang sesuai dan menggunakan sumber belajar secara optimal (Dewantari \& Hariyatmi, 2015, p.1).

\section{Transaction (Pelaksanaan Pembelajaran)}

Hasil penelitian terhadap aspek pelaksanaan (transaction) pembelajaran model discovery learning dalam pembelajaran IPA di SMP disajikan dalam Tabel 3. Hasil analisis data menunjukkan guru IPA telah mampu untuk melakukan pengkondisian peserta didik, menjelaskan kompetensi yang akan

Tabel 2. Matrik Countenance Aspek Antecendent

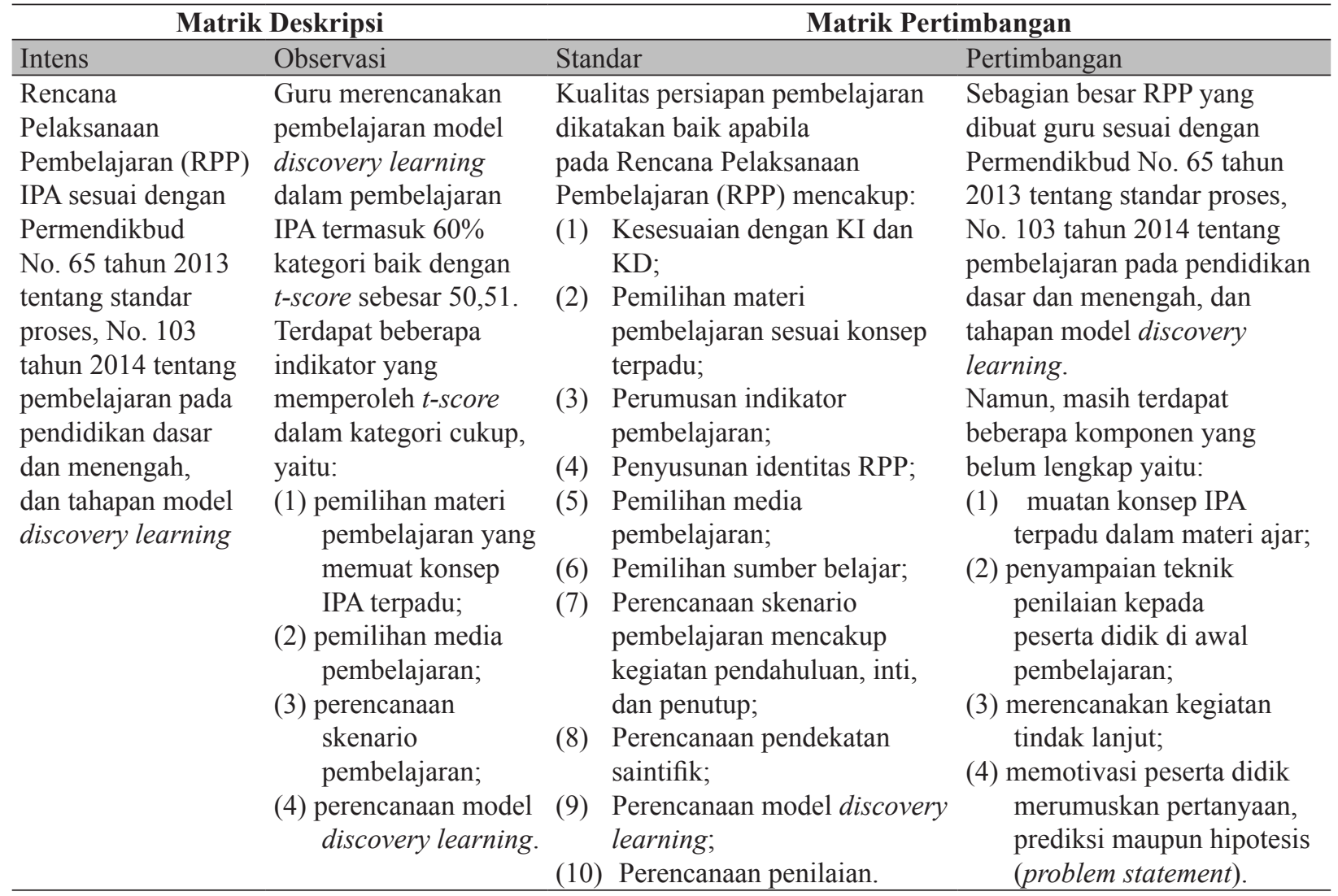


Tabel 3. Matrik Countenance Aspek Transaction Pembelajaran

\begin{tabular}{|c|c|c|c|}
\hline \multicolumn{2}{|r|}{ Matrik Deskripsi } & \multicolumn{2}{|c|}{ Matrik Pertimbangan } \\
\hline Intens & Observasi & Standar & Pertimbangan \\
\hline $\begin{array}{l}\text { Guru IPA } \\
\text { melaksanakan } \\
\text { pembelajaran } \\
\text { sesuai dengan } \\
\text { Permendikbud } \\
\text { No. } 65 \text { tahun } \\
2013 \text { tentang } \\
\text { standar proses dan } \\
\text { No. } 103 \text { tahun } \\
2014 \text { tentang } \\
\text { pembelajaran } \\
\text { pada pendidikan } \\
\text { dasar dan } \\
\text { menengah. } \\
\text { Guru } \\
\text { melaksanakan } \\
\text { pembelajaran } \\
\text { sesuai dengan } \\
\text { tahapan model } \\
\text { discovery } \\
\text { learning. }\end{array}$ & $\begin{array}{l}\text { Pelaksanaan model discovery } \\
\text { learning dalam pembelajaran IPA } \\
\text { secara keseluruhan } 75,85 \% \text { kategori } \\
\text { baik dengan rerata } t \text {-score sebesar } \\
\text { 51,32, dengan rincian sebagai } \\
\text { berikut. } \\
\text { (1) Kegiatan pembelajaran yang } \\
\text { dilaksanakan mencakup } \\
\text { kegiatan pendahuluan } 83,33 \% \\
\text { kategori baik dengan rerata } \\
\text { t-score sebesar 55,99, kegiatan } \\
\text { inti } 69,23 \% \text { kategori baik } \\
\text { dengan rerata } t \text {-score sebesar } \\
\text { 48,65 dan kegiatan penutup } \\
75 \% \text { kategori baik rerata } t \text {-score } \\
\text { sebesar } 49,32 \text {. } \\
\text { (2) Pelaksanaan pembelajaran } \\
\text { dengan tahapan model discovery } \\
\text { learning } 66,67 \% \text { kategori baik } \\
\text { dengan rerata } t \text {-score sebesar } \\
\text { 49,39. Tahap stimulation, data } \\
\text { collection, data processing, } \\
\text { dan generalization termasuk } \\
\text { kategori baik. Tahap problem } \\
\text { statement dan verification } \\
\text { termasuk kategori cukup. }\end{array}$ & $\begin{array}{l}\text { Kualitas pelaksanaan } \\
\text { pembelajaran dikatakan baik } \\
\text { apabila: } \\
\text { (1) Kegiatan pembelajaran } \\
\text { mencakup kegiatan } \\
\text { pendahuluan, inti dan } \\
\text { penutup; } \\
\text { (2) Kesesuaian dengan } \\
\text { model discovery } \\
\text { learning, mencakup tahap } \\
\text { stimulation (stimulasi/ } \\
\text { pemberian rangsangan), } \\
\text { problem statement } \\
\text { (pernyataan/ identifikasi } \\
\text { masalah), data collection } \\
\text { (pengumpulan data), data } \\
\text { processing (pengolahan } \\
\text { data), verification } \\
\text { (pembuktian), dan } \\
\text { generalization (menarik } \\
\text { kesimpulan/ generalisasi). }\end{array}$ & $\begin{array}{l}\text { Pada umumnya guru } \\
\text { telah melaksanakan } \\
\text { pembelajaran sesuai } \\
\text { dengan Permendikbud } \\
\text { No. } 65 \text { tahun } 2013 \\
\text { tentang standar proses } \\
\text { dan No. } 103 \text { tahun } 2014 \\
\text { tentang pembelajaran } \\
\text { pada pendidikan } \\
\text { dasar dan menengah. } \\
\text { Guru melaksanakan } \\
\text { pembelajaran sesuai } \\
\text { dengan tahapan model } \\
\text { discovery learning. } \\
\text { Tahap yang masih } \\
\text { perlu ditingkatkan yaitu } \\
\text { kemampuan peserta } \\
\text { didik untuk merumuskan } \\
\text { pertanyaan, prediksi, } \\
\text { dan hipotesis (problem } \\
\text { statement), serta } \\
\text { membuktikannya. }\end{array}$ \\
\hline
\end{tabular}

dicapai, menyampaikan rencana kegiatan pembelajaran, cakupan materi, teknik penilaian, serta menimbulkan rasa ingin tahu peserta didik dalam kegiatan pendahuluan.

Hasil temuan menunjukkan peserta didik masih menemui kesulitan untuk merumuskan pertanyaan, prediksi, dan hipotesis (problem statement) dan verification (pembuktian). Hasil ini menunjukkan bahwa kegiatan awal yang dilakukan guru untuk memberikan stimulasi kepada peserta didik belum mampu mengarahkan peserta didik untuk membuat hipotesis. Hal ini dikarenakan guru lebih sering memanfaatkan media belajar seperti gambar, membaca buku, maupun melalui alam sekitar tanpa memberikan arahan. Kesulitan peserta didik dalam merumuskan prediksi dan hipotesis dikarenakan guru kurang dapat memberikan pertanyaan dan pernyataan yang mengarahkan peserta didik dalam membuat dugaan sementara. Hasil ini didukung penelitian yang melaporkan bahwa implementasi pembelajaran IPA belum maksimal karena guru kurang kreatif untuk mengajukan pertanyaan-pertanyaan yang menantang siswa untuk bertanya (Hakim, 2015, p.vii).

Tahap merumuskan pertanyaan, prediksi, dan hipotesis (problem statement) yang belum dapat terlaksana dengan baik mengakibatkan verification (pembuktian) juga belum terlaksana dengan baik. Hal ini menunjukkan pola berpikir ilmiah peserta didik belum dapat dikatakan baik. Peserta didik cenderung hanya melaksanakan tugas dari guru tanpa mengetahui maksud dari proses pembelajaran tersebut. Oleh karena itu, guru harus memberikan klarifikasi pada tahap penarikan kesimpulan pembelajaran. Pada kegiatan penutup peserta didik telah dapat membuat kesimpulan dengan bimbingan guru dan dapat membuat laporan hasil kegiatan dengan baik. Guru melaksanakan kegiatan umpan balik kepada peserta didik, menilai 
Tabel 4. Matrik Countenance Aspek Transaction Penilaian

\begin{tabular}{|c|c|c|c|}
\hline \multicolumn{2}{|r|}{ Matrik Deskripsi } & \multicolumn{2}{|c|}{ Matrik Pertimbangan } \\
\hline Intens & Observasi & Standar & Pertimbangan \\
\hline $\begin{array}{l}\text { Guru melaksanakan } \\
\text { penilaian hasil } \\
\text { belajar peserta didik } \\
\text { sesuai Permendikbud } \\
\text { nomor } 65 \text { tahun } \\
2013 \text { dan } 103 \\
\text { tahun } 2014 \text { tentang } \\
\text { pembelajaran, serta } \\
\text { nomor } 66 \text { tahun } 2013 \\
\text { dan } 104 \text { tahun } 2014 \\
\text { tentang penilaian } \\
\text { hasil belajar. }\end{array}$ & $\begin{array}{l}\text { Secara keseluruhan penilaian hasil } \\
\text { belajar yang dilakukan guru } 71,43 \% \\
\text { kategori baik dengan rerata } t \text {-score } \\
\text { sebesar } 50,59 \text {. } \\
\text { (1) Pelaksanaan penilaian mencakup } \\
\text { (a) penilaian aspek sikap kategori } \\
\text { cukup dengan } t \text {-score sebesar } \\
47,55 \\
\text { (b) penilaian aspek pengetahuan } \\
\text { kategori baik dengan } t \text {-score } \\
\text { sebesar } 55,32 \\
\text { (c) penilaian aspek keterampilan } \\
\text { kategori cukup dengan } t \text {-score } \\
\text { sebesar } 42,32 \text {. } \\
\text { (2) Analisis penilaian kategori baik } \\
\text { dengan } t \text {-score sebesar } 51,72 \\
\text { (3) Pelaporan penilaian kategori baik } \\
\text { dengan } t \text {-score sebesar } 54,36\end{array}$ & $\begin{array}{l}\text { Kualitas pelaksanaan } \\
\text { penilaian hasil belajar } \\
\text { dikatakan baik apabila } \\
\text { mencakup: } \\
\text { (1) Pelaksanaan } \\
\text { penilaian } \\
\text { mencakup } \\
\text { penilaian aspek: } \\
\text { (a) sikap, } \\
\text { (b) pengetahuan dan } \\
\text { (c) keterampilan; } \\
\text { (2) Analisis penilaian; } \\
\text { dan } \\
\text { (3) Pelaporan } \\
\text { penilaian. }\end{array}$ & $\begin{array}{l}\text { Guru telah melakukan } \\
\text { penilaian hasil belajar } \\
\text { peserta didik sesuai } \\
\text { Permendikbud nomor } 65 \\
\text { tahun } 2013 \text { dan } 103 \text { tahun } \\
2014 \text { tentang pembelajaran, } \\
\text { serta nomor } 66 \text { tahun } 2013 \\
\text { dan } 104 \text { tahun } 2014 \text { tentang } \\
\text { penilaian hasil belajar. } \\
\text { Guru perlu meningkatkan } \\
\text { pelaksanaan penilaian } \\
\text { otentik sesuai Kurikulum } \\
2013 \text { terutama pada } \\
\text { aspek penilaian sikap dan } \\
\text { keterampilan. }\end{array}$ \\
\hline
\end{tabular}

hasil belajar, dan guru juga menyampaikan kepada peserta didik tentang rencana kegiatan pembelajaran berikutnya.

Hasil temuan menunjukkan guru telah melaksanakan menilaian dalam aspek pengetahuan yang mencakup penilaian dengan tes tertulis maupun tes lisan. Penilaian keterampilan dilakukan melalui penilaian produk, proyek dan saat melakukan kegiatan praktikum. Laporan akhir penilaian tertuang dalam buku rapor peserta didik, sedangkan hasil belajar harian juga perlu diketahui oleh peserta didik. Berdasarkan wawancara dan pengamatan, terdapat beberapa guru telah membiasakan untuk menyampaikan hasil belajar peserta didik baik pada ulangan harian maupun tugas lain. Hal ini penting karena dapat meningkatkan semangat belajar peserta didik. Beberapa guru menyampaikan bahwa mengalami kesulitan dalam menilai sikap dan keterampilan peserta didik dalam jumlah yang dirasa cukup banyak yaitu kurang lebih 30 peserta didik setiap kelasnya. Penilaian aspek keterampilan dipilih alternatif oleh guru dengan melakukan penilaian dalam kelompok kerja sehingga lebih mudah dalam pengamatan. Hasil yang sama juga ditemukan dalam penelitian yang menemukan bahwa pelaksanaan penilaian kompetensi sikap masih menjadi kendala dalam pelaksanaan Kurikulum 2013 (Putri, 2016, p.ii).

\section{Outcomes (Hasil Belajar)}

Hasil penelitian terhadap hasil belajar peserta didik dalam penerapan model discovery learning pembelajaran IPA di SMP disajikan dalam Tabel 5. Keberhasilan pembelajaran dapat diamati melalui perolehan hasil belajar peserta didik. Hasil belajar peserta didik dalam kompetensi pengetahuan dapat teramati melalui hasil tes tertulis seperti ulangan harian. Hasil ulangan harian materi pokok interaksi makhluk hidup dan lingkungan telah mencapai ketuntasan atau melampaui kriteria ketuntasan minimal sebesar 75. Hasil perolehan ini menunjukkan bahwa 79,86\% peserta didik telah memahami konsep dalam materi pokok tersebut dengan baik. Hal ini sesuai dengan penelitian bahwa model discovery learning memiliki pengaruh signifikan terhadap pemahaman konsep IPA peserta didik (Widiadnyana et al., 2014). Di sisi lain, hasil ini juga menunjukkan masih terdapat $20,14 \%$ peserta didik yang belum mencapai ketuntasan sehingga harus melaksanakan program tindak lanjut berupa remedi. 
Tabel 5. Matrik Countenance Aspek Outcomes

\begin{tabular}{|c|c|c|c|}
\hline \multicolumn{2}{|r|}{ Matrik Deskripsi } & \multicolumn{2}{|c|}{ Matrik Pertimbangan } \\
\hline Intens & Observasi & Standar & Pertimbangan \\
\hline $\begin{array}{l}\text { Hasil belajar } \\
\text { memenuhi Kriteria } \\
\text { Ketuntasan } \\
\text { Minimal (KKM) } \\
\text { sebesar } 75 \%\end{array}$ & $\begin{array}{l}\text { Hasil belajar peserta didik mencakup } \\
\text { tiga aspek berikut. } \\
\text { 1. Kompetensi pengetahuan mencapai } \\
\text { ketuntasan sebesar } 79,86 \% \text { dengan } \\
\text { nilai rata-rata } 79,85 \text {. } \\
\text { 2. Kompetensi keterampilan mencapai } \\
\text { ketuntasan } 100 \% \text { dengan nilai rata- } \\
\text { rata } 83,23 \text {. } \\
\text { 3. Kompetensi sikap mencapai } \\
\text { ketuntasan } 100 \% \text { dengan nilai rata- } \\
\text { rata } 81,16 \text {. }\end{array}$ & $\begin{array}{l}\text { Ketercapaian hasil } \\
\text { belajar } 75 \% \text { peserta } \\
\text { didik memenuhi } \\
\text { Kriteria Ketuntasan } \\
\text { Minimal (KKM). }\end{array}$ & $\begin{array}{l}\text { Sebagian besar peserta } \\
\text { didik telah memenuhi } \\
\text { KKM. } \\
\text { Guru perlu mengadakan } \\
\text { pembelajaran remedi } \\
\text { untuk memperbaiki } \\
\text { pemahaman peserta didik } \\
\text { yang belum mencapai } \\
\text { KKM. }\end{array}$ \\
\hline
\end{tabular}

Ketidaktuntasan tersebut dimungkinkan karena perbedaan kemampuan masing-masing peserta didik mengkonstruksi pengetahuan atau konsep IPA yang dipelajari melalui model discovery learning. Kompetensi keterampilan dan sikap mencapai ketuntasan maksimal (100\%) dengan nilai rata-rata lebih dari 80 . Hasil ini menunjukkan bahwa keterampilan dan sikap peserta didik termasuk kategori baik. Peserta didik memiliki keterampilan yang baik dapat dikarenakan tahapan dalam proses pembelajaran yang mereka alami. Pembelajaran secara berkelompok juga dapat membuat peserta didik saling membantu. Ketercapaian maksimal pada kompetensi keterampilan dan sikap dapat disebabkan karena instrumen penilaian yang dibuat guru kurang dapat membedakan kemampuan antar peserta didik. Praktik belajar berkelompok dengan jumlah peserta didik yang banyak juga dapat mempersulit penilaian yang dilakukan guru. Hal ini sesuia dengan penelitian yang menyebutkan bahwa hambatan yang dihadapi guru dalam implementasi Kurikulum 2013 yaitu guru kesulitan membuat instrument penilaian portofolio dan belum maksimal dalam memfungsikan instrument penilaian sikap (Fadilah \& Suparwoto, 2016).

\section{KESIMPULAN}

Kualitas persiapan penerapan model discovery learning dalam pembelajaran IPA di SMP termasuk kategori baik. Beberapa komponen dalam RPP yang masih perlu dilengkapi yaitu adanya muatan konsep IPA terpadu dalam materi ajar, penyampaian teknik penilaian kepada peserta didik di awal pembelajaran, merencanakan kegiatan tindak lanjut dengan lebih jelas, dan perencanaan untuk memotivasi peserta didik dalam merumuskan pertanyaan, prediksi maupun hipotesis (problem statement).

Kualitas proses pelaksanaan penerapan model discovery learning dalam pembelajaran IPA di SMP termasuk kategori baik. Hal ini didukung dengan temuan bahwa kesesuaian kegiatan pembelajaran dengan Kurikulum 2013 pada kegiatan pendahuluan, kegiatan inti, kegiatan penutup, dan pelaksanaan penilaian hasil belajar termasuk kategori baik. Kesesuaian pelaksanaan pembelajaran dengan tahapan model discovery learning termasuk kategori baik. Guru perlu meningkatkan proses memotivasi peserta didik dalam merumuskan pertanyaan, prediksi maupun hipotesis (problem statement) serta meningkatkan pelaksanaan penilaian sesuai Kurikulum 2013 terutama pada penilaian aspek sikap dan keterampilan.

Hasil belajar peserta didik telah tercapai yaitu mencakup kompetensi pengetahuan mencapai nilai rata-rata sebesar 79,85, kompetensi keterampilan mencapai nilai rata-rata sebesar 83,23, dan kompetensi sikap mencapai nilai rata-rata sebesar 81,16. Guru perlu mengadakan pembelajaran remedi untuk memperbaiki pemahaman peserta didik yang belum mencapai KKM. 


\section{DAFTAR PUSTAKA}

Alfieri, L., Brooks, P. J., Aldrich, N. J., \& Tenenbaum, H. R. (2011). Does DiscoveryBased Instruction Enhance Learning? Journal of Educational Psychology. https:// doi.org/10.1037/a0021017

Apriyadi, A. (3 Januari 2016). Jumlah sekolah terapkan kurikulum 2013 di Bantul ditargetkan bertambah. Tribun Jogja [Versi Elektronik]. Diambil tanggal 3 Maret 2016 dari http://jogja.tribunnews. com/2016/01/03/.

Arend, R. I. (2014). Learning to teach (10 $0^{\text {th }}$ ed). New York: McGraw-Hill international Edition.

Arifin, Z. (2014). Evaluasi pembelajaran prinsip, teknik, prosedur. Bandung: PT. Remaja Rosdakarya Offset.

Champine, S. L., Duffy, S. M., \& Perkins, J. R. (2009). Jerome S . Bruner "s Discovery Learning Model as the Theoretical Basis of Light Bounces Lesson. Educational Psychologist.

Collette, A.T \& Chiapetta. (1994). Science instruction in the middle and secondary schools. New York: Macmillan Publishing Company.

Dewantari, P.M.A\& Hariyatmi (2015). Identifikasi kesulitan guru ipa dalam melaksanakan pembelajaran kurikulum 2013 di SMP Negeri 1 Wonogiri Tahun Pelajaran 2014/2015. Artikel Publikasi Ilmiah, Universitas Muhammadiyah Surakarta, Surakarta.

Fadilah, N. U., \& Suparwoto, S. (2016). Keterlaksanaan pembelajaran fisika implementasi kurikulum 2013 berdasarkan latar belakang akademik guru di MAN DIY. Jurnal Inovasi Pendidikan IPA. https://doi. org/10.21831/jipi.v2i1.8380

Fitzpatrick, J.L., Sanders, J.R., \& Worthen, B.R. (2011). Program evaluation: alternative approaches and practical guidelines. New Jersey: Pearson Education.

Hakim, M. L. (2015). Implementasi pembelajaran IPA dengan pendekatan saintifik (studi kasus di MI Negeri Cisambeng Majalengka).
Tesis magister, tidak diterbitkan, UIN Sunan Kalijaga, Yogyakarta.

Hewitt, P. (1999). Conceptual Physics. The Physics Teacher. https://doi. org/10.1119/1.880288

Hewitt, P. G., Lyons, S. A., Suchocki, J. A., \& Yeh, J. (2013). Conceptual Integrated Science: International Edition.

Lukum,A. (2015). EVALUASI PROGRAM PEMBELAJARAN IPA SMP MENGGUNAKA N M O DEL COUNTENANCE STAKE. Jurnal Penelitian Dan Evaluasi Pendidikan. https://doi.org/10.21831/pep.v19i1.4552

Mendikbud. (2013). Peraturan Menteri Pendidikan dan Kebudayaan RI Nomor 65, Tahun 2013, tentang Standar Proses Pendidikan Dasar dan Menengah.

Mulyasa, E. (2015). Pengembangan dan implementasi kurikulum 2013. Bandung: PT. Remaja Rosdakarya.

Putri, R. F. (2016). Kemampuan guru fisika SMA Negeri di Kabupaten Sleman dalam menerapkan model-model pembelajaran yang ditentukan pada kurikulum 2013 serta kendala-kendala yang dihadapi. Tesis. Universitas Negeri Yogyakarta.

Stake, R. E. (1967). The Countenance of Educational Evaluation. Teachers College Record. https://doi.org/10.1017/ CBO9781107415324.004

Sugiyono. (2014). Metode penelitian kuantitatif, kualitatif dan $R \& D$. Bandung: ALFABETA.

Syah, M. (2008). Psikologi pendidikan: dengan pendekatan baru. Bandung: PT Remaja Rosdakarya.

Widiadnyana, Sadia, \& Suastra. (2014). Pengaruh Model Discovery Learning Terhadap Pemahaman Konsep IPA dan Sikap Ilmiah Siswa SMP. E-Journal Program Pascasarjana Universitas Pendidikan Ganesha Program Studi IPA. Widoyoko, S.E.P. (2015). Evaluasi program pembelajaran (panduan praktis bagi pendidik dan calon pendidik). Yogyakarta: Pustaka Pelajar. 